\title{
REVIEW AND COMPARISON OF WATER EROSION INTENSITY IN THE WESTERN BALKAN AND EU COUNTRIES
}

\author{
Ivan Blinkov \\ Department of Land and Water, Faculty of Forestry, Ss. Cyril and Methodius University, \\ Skopje, Republic of Macedonia \\ e-mail: blinkov@sf.ukim.edu.mk
}

\begin{abstract}
The south and southeast region of Europe is significantly prone to water erosion. In parts of the region, erosion has reached a stage of irreversibility and in some places erosion has practically ceased because there is no soil left. In the recent period several models and approaches in a GIS environment were developed using available database for erosion factors on the European level on which data about water erosion in Western Balkan countries is missing. Scientists in the Western Balkan countries faced with the erosion problem for years, developed own models or prepared various erosion risk maps using national databases. The aim of this study is to compare results of water erosion intensity in the Western Balkan countries using models on wider level (European maps) and national researches. The basic methodological approach in this paper is an analysis of secondary data, using the method of "content analysis" of various data sources. Inductive and deductive qualitative analyses were used and finally the method of "comparative analysis" is applied, too. Through the analysis of national researches it was estimated that erosion intensity in the WB countries is $656 \mathrm{~m}^{3} / \mathrm{ha}$ (similar to $6.56 \mathrm{t} / \mathrm{ha}$ ) and the total amount of annual produced erosive material is $373.8 \cdot 10^{6} \mathrm{~m}^{3}$. The most erosive countries in Europe are Albania and Montenegro where mean annual intensity of erosion is $>10$ t/ha. Macedonia together with Italy, Portugal, Slovenia and Romania is in the second group of countries, where erosion intensity is $5-10$ t/ha.
\end{abstract}

Key words: erosion map; erosion intensity; erosion risk

\section{INTRODUCTION}

Soil erosion is considered as one of the major threats to European soils, particularly in the Mediterranean areas (Communication on Soil Protection - "Towards a Thematic Strategy for Soil Protection", CEC, 2002). In order to effectively formulate mitigation strategies and implement conservation measures to counteract soil erosion, it is essential to objectively identify and quantify areas at risk (Gobin et al., 2002). Erosion is understood to be a physical phenomenon that results in the displacement of soil and rock particles by water, wind, ice and gravity.

The south and southeast region of Europe is significantly prone to water erosion. In parts of the region, erosion has reached a stage of irreversibility and in some places erosion has practically ceased because there is no soil left. With a very slow rate of soil formation, any soil loss of more than $1 \mathrm{t} / \mathrm{ha} / \mathrm{y}$ can be considered as irreversible within a time span of 50-100 years. Losses of 20 to $40 \mathrm{t} / \mathrm{ha}$ in individual storms, that may happen once every few years, are measured regularly in Europe with losses of more than 100 t/ha in extreme events (Morgan, 1992). It may take some time before the effects of such erosion become noticeable, especially in areas with the deepest and most fertile soils or on heavily fertilized land. However, this is more dangerous because, once the effects have become obvious, it is usually too late to do anything about it.

In the last years there was a huge development in the use of GIS in spatial analysis of the various aspects including erosion risk issues. Various methods, models and approaches for erosion risk assessment are used by various countries in Europe. 
Generally, three types of approaches exist to identify areas at risk (Eckelmann et al., 2006): qualitative, quantitative and model approaches.

There is a significant difference within the scientific community in several erosion related issues as follows: definition and acceptance of erosion, erosion intensity measurements, erosion intensity modeling which particularly depends on a scientist provenience (various schools, various professions, etc.). On European level, there is no unified classification of erosion or unified model for erosion intensity and risk. In the oldest reports about water erosion on world or European level there is data about WB countries.

In the recent period there were developed several models and approaches in a GIS environment using available database for erosion factors on the European level. In the most of recent scientific projects launched by JRC (Joint Research Centre of Europe) and other scientific institutions in Europe, research were focused on EU countries and data about water erosion in Western Balkan countries is missing.

Within the EEA (European Environment Agency) reports data on water erosion in all Europe countries could be found.

Scientists in the Western Balkan countries, faced with the erosion problem for years, developed own models or prepared various erosion risk maps using national databases. There is significant a difference in the results got using various models or results got on wider especially European level and national level.

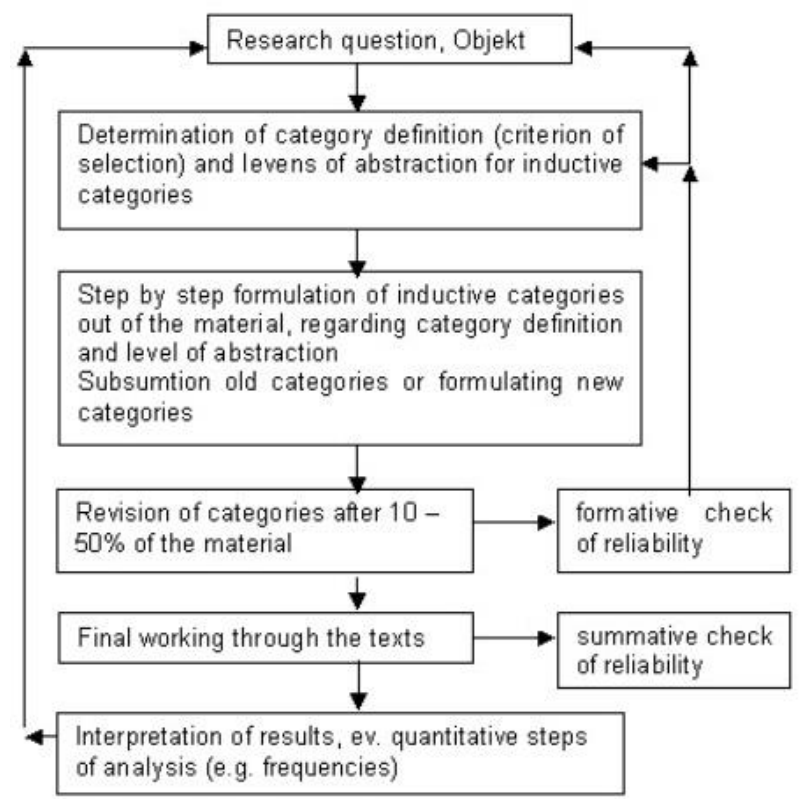

a)
All that mentioned above was the reason for launching this study.

\section{AIMS AND METHODOLOGY}

The aim of this study is to compare results of water erosion intensity in the Western Balkan countries done using models on wider level (European maps) and national researches.

The objectives of this study are as follows:

- analysis of results of erosion intensity on world or European level,

- analysis of results of erosion intensity on national level of WB countries,

- comparison of results.

Research methodology was adapted to the objective needs.

The basic methodological approach in this paper is an analysis of secondary data, using the method of "content analysis" of various data sources. This method is used for research of written documents. Before starting the analysis it was decided what would be the sample for analysis, and the sample can be a word, sentence, data, map or other item that corresponds with the survey.

Inductive and deductive qualitative analyses were used during the first two objectives

The method of "comparative analysis", used for the third objective, is applied to each of them comparing similar phenomena, classification and categorization, which are related to the subject of the research. This method is used to determine the difference that needs to be addressed.

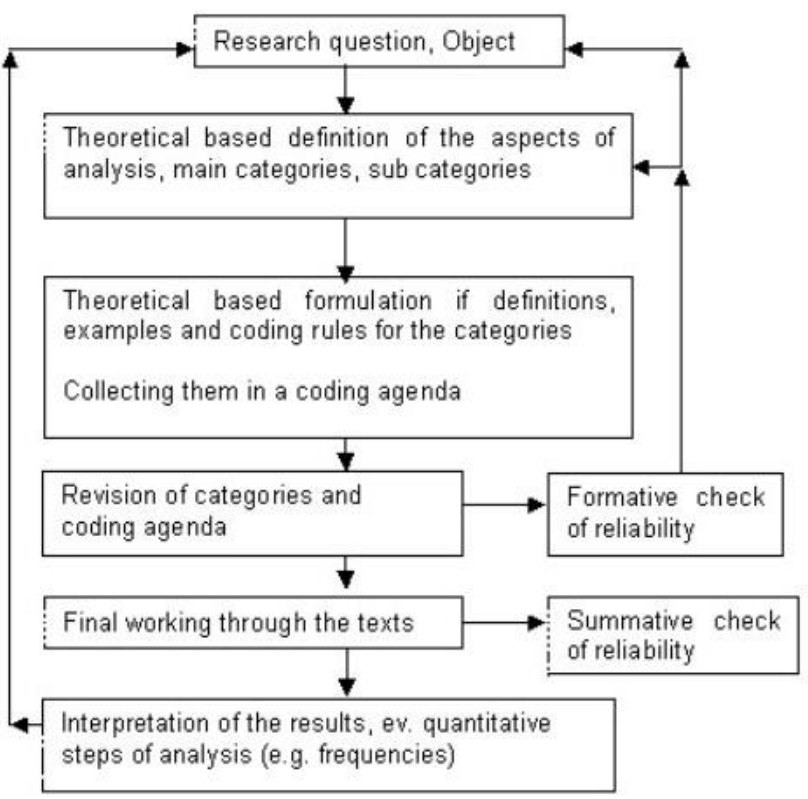

b)

Figure 1. Step models of a) inductive and b) deductive category application by Mayring, 2000 
The complexity of the process of erosion, as well as modeling, requires a comprehensive analysis of a number of secondary data sources, which are analyzed documents, goals, and special emphasis is laid on the situation of erosion, in the sense: Which model is used? What is the applicability of the model to define various processes of erosion? What factors/data are used by the model, and what is their precision? What are the results? What are the differences between the results? What is the reason for these differences?

A wide list of projects, scientific papers and data was analyzed in the preliminary phase while the focus of the research was aimed to the results from the following:

\section{- Projects:}

- SERA (Soil Erosion Risk Assessment) in Europe - EC - ESB - JRC, 2000.

- PESERA (Pan European Soil Erosion Risk Assessment) Model, EC-JRC-IES, http://eusoils.jrc. ec.europa.eu/ESDB Archive/pesera/pesera cd/index. $\underline{\mathrm{htm}}$.

- MESALES (Modèle d'Evaluation Spatiale de l'ALéa Erosion des Sols - Regional Modeling of Soil Erosion Risk) Assessment in Europe, EC-JRS, IES, INRA, http://eusoils.jrc.ec.europa.eu/ ESDB Archive/serae/grimm/erosion/inra/europe/an alysis/maps and listings/web erosion/index.html.

\section{-Other EC sources:}

- EC - EEA (European IEnvironment Agency) - annual reports - SOER;

- EC - ES (Eurostat), Agri-environmental indicator - soil erosion, data, http://epp.eurostat.ec.
europa.eu/statistics_explained/index.php/Agri-environmental_indicator_-_soil_erosion;

- Soil Erosion in Europe, book, Willy\&Sons, Editor(s): John Boardman, Jean Poesen, 2006;

WB countries national reports, database and maps prepared by various scientists:

- Albania (Grazhdani, Shumka, Zdruli, Ljusaj),

- Bosnia and Herzegovina (Lazić, Tošić, Custović, Marković)

- Croatia (Husnjak, Bogunović, Bekić),

- Serbia, Montenegro and Kosovo (Kostadinov, Zlatić, Dragović, Gavrilović),

- Macedonia (Gorgević, Jelić, Trendafilov, Georgievski, Popovski).

used:

The following three criteria for analysis were

- erosion intensity expression ( $\mathrm{t} / \mathrm{ha}$ or $\mathrm{m}^{3} / \mathrm{km}^{2}$ ),

- working (map) scale and

- used methodology.

\section{THEORETICAL BACKGROUND}

The main forms of water erosion are:

- pluvial erosion (caused by rainfall "bomb-

ing" - 'rainsplash erosion', sheet erosion);

- pluvial-fluvial (when water from rainfalls running on the slopes combines with direct hit of rainfalls - rills, gullies);

- mass-movement erosion (slips, landslides, lanfalls, rockfalls even weathering);

- streambank (fluvial) erosion.

All these processes generate erosive material that is subject of transport. This material could stop somewhere on the catchment, could stay or be transported to the final recipient.

Table 1. Possible erosion intensity by E. Roose (2002)

\begin{tabular}{|c|c|c|}
\hline \multicolumn{3}{|c|}{ Sheet erosion: Interrill erosion: $1 \mathrm{t} / \mathrm{ha}$ year $-15 \mathrm{t} / \mathrm{ha}$ year } \\
\hline $\mathrm{S} 1$ & $1 \mathrm{t} / \mathrm{ha}$ & local traces of sealing crust and loam SOM deposit \\
\hline S2 & $4 \mathrm{t} / \mathrm{ha}$ & sealing crust localized, with loamy sediments \\
\hline S3 & $8 \mathrm{t} / \mathrm{ha}$ & topsoil frequently crusted with coarse sandy sheet deposits \\
\hline S4 & $12 \mathrm{t} / \mathrm{ha}$ & pedestal, micro-cliffs and crusts, or gravel deposits \\
\hline S5 & $15 \mathrm{t} / \mathrm{ha}$ & very large rills scouring only the humiferous tilled topsoil \\
\hline \multicolumn{3}{|c|}{ Linear erosion: $10 \mathrm{t} / \mathrm{ha}$ year $-150 \mathrm{t} / \mathrm{ha}$ year } \\
\hline L1 & $10 \mathrm{t} / \mathrm{ha}$ & little rills of $<10 \mathrm{~cm}$ depth \\
\hline L2 & $30 \mathrm{t} / \mathrm{ha}$ & rills of $10 \mathrm{~cm}-30 \mathrm{~cm}$ depth, \\
\hline L3 & $60 \mathrm{t} / \mathrm{ha}$ & deep rills and ephemeral gullies $($ depth $>30 \mathrm{~cm}$ \\
\hline L4 & $100 \mathrm{t} / \mathrm{ha}$ & gullies frequent or wide or deep \\
\hline L5 & $150 \mathrm{t} / \mathrm{ha}$ & badland where gullies have scoured completely the soil surface \\
\hline \multicolumn{3}{|c|}{ Mass movement erosion: $20 \mathrm{t} / \mathrm{ha}$ year $-500 \mathrm{t} / \mathrm{ha}$ year } \\
\hline M1 & $20 \mathrm{t} / \mathrm{ha}$ & slow creeping of the topsoil \\
\hline M2 & $40 \mathrm{t} / \mathrm{ha}$ & tillage erosion from the hilltop to the embankment of the field limit \\
\hline M3 & $100 \mathrm{t} / \mathrm{ha}$ & landslide on a superficial soil \\
\hline M4 & $200 \mathrm{t} / \mathrm{ha}$ & landslide with rotation \\
\hline M5 & $500 \mathrm{t} / \mathrm{ha}$ & undermining of river banks and of hill slopes by the river \\
\hline
\end{tabular}


Annual erosion intensity (eroded or deposed material) can be expressed using the following measures: depth $-[\mathrm{mm}]$ changed soil layer, volume $-\mathrm{m}^{3} / \mathrm{km}^{2}$ or $\mathrm{m}^{3} /$ ha and weight $-\mathrm{t} / \mathrm{km}^{2}$ or $\mathrm{t} / \mathrm{ha}$. Natural (geological, slow) erosion intensity is 70 $100 \mathrm{~m}^{3} / \mathrm{km}^{2}$; 0.07-0.1 t/ha or $0.1 \mathrm{~mm}$. On the other hand, the anthropogenic (accelerated) erosion intensity is several times higher - up to 50000 $\mathrm{m}^{3} / \mathrm{km}^{2}, 500 \mathrm{t} / \mathrm{ha}, 50 \mathrm{~mm}$.

Erosion damages are of interest to various sectors. Interest of various sector are different and adopted to the sectoral needs. That is one of the reasons for usage of different approaches and methodologies.

In order to predict and also prevent soil erosion it is necessary to assess the potential and actual risks of soil erosion. For assessment of soil erosion risk, various approaches have been adopted, especially in the recent period. All these recent methods use geospatial databases developed by using GIS technology. A problem with most of the methods based on scoring is that the results are affected by the way the scores are defined. In addition to this, the classifying of the source data, for e.g. slope classes, results in information loss, and the results of the analyses may depend strongly on the class limits and the number of classes used. Moreover, unless some kind of weighting is used, each factor is given equal weight, which is not realistic (Grimm, Jones, Montanarela, 2002).

A wide variety of models are available for assessing soil erosion risk. USLE (Universal Soil Loss Equation) with its variants is the most used method in the world. It should be stressed that a lot of models as SWAT or STREAM are in fact complex computerized models that encompass several topics related to soil and water, but in the part of erosion USLE method is involved in the models. On the territory of ex-Yugoslavia, Erosion Potential Model (EPM) was established by Gavrilović.( Gavrilović, S., 1972). For agricultural engineering needs, the most appropriate method is USLE, but EPM is the most appropriate method for estimation of off-site damages (especially of the total annual transported material to any reservoir). Related to the watershed management need, the EPM is the most comprehensive method because it gives solution to almost all tasks (Blinkov and Kostadinov, 2010). However, results obtained by using different methods are not similar but very often there is a huge difference between them which creates dilemmas within the scientific-expert society and especially on the policy level.

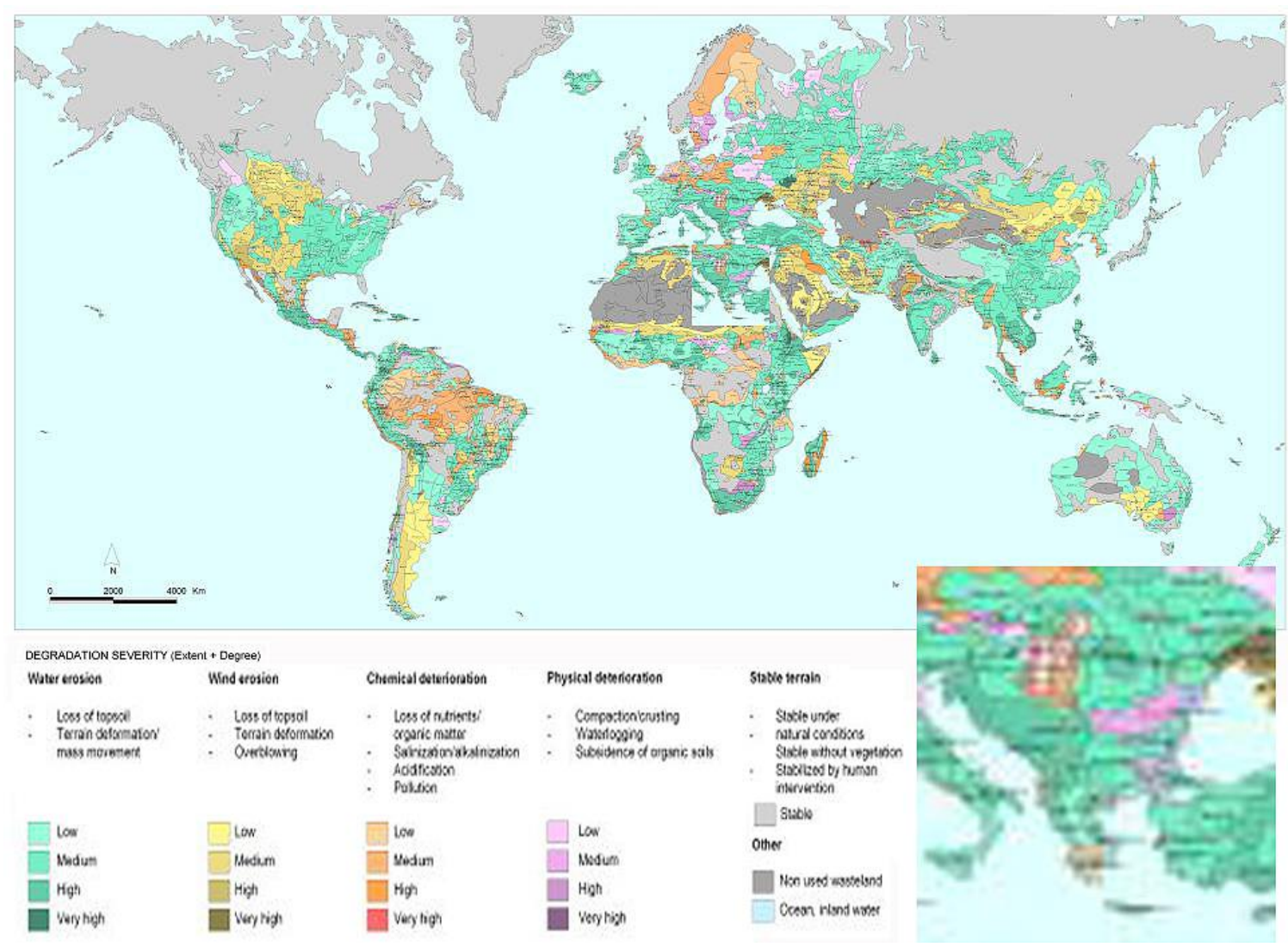

Figure 2. Global assessment of human-induced soil degradation processes (GLASOD, 1990) 


\section{RESULTS AND DISCUSSION} jectives.

Results are presented following the three ob-

\section{Water erosion intensity on world level}

\section{a) GLASOD project, 1990}

Various types of degradation processes affect soils in the world. The first attempt to combine various types of human-induced soil degradation processes was done by Oldeman through the GLASOD project.

The above map shows that water erosion is a dominant degradation process of soils in the world. While the chemical degradation processes are dominant in North Europe, water erosion is the dominant soil degradation process in South and WB countries.

Soil erosion remains the world's biggest environmental problem, threatening both developed and developing countries. (12 ${ }^{\text {th }}$ International Soil Conservation Organization (ISCO) Conference). Half of the topsoil on the planet was lost in the last 150 years. (http://www.worldwildlife.org/threats/ soil-erosion-and-degradation).

About 65 percent of the soil on earth display degradation phenomena, such as erosion, desertification and salinization. In Europe, 12 percent of the soil is threatened by water erosion, and four percent by wind erosion. Soil erosion is also found on 95 million hectares of land in North America and 500 million hectares in Africa. Economic losses from water and soil erosion as well as salinization in South Asia have accumulated to 5.4 billion, 1.8 billion and 1.5 billion U.S. dollars, respectively. China faces one of the most serious soil erosion problems in the world. The latest remote-sensing survey shows that the country has some 3.56 million square kilometers of soil erosion areas, accounting for 37 percent of China's total territory. http://english.peopledaily.com.cn/200205/28/eng20 020528 96615.shtml.

\section{b) USDA - NCRS, 1998}

Data about water erosion on world level were found on the USDA (United States Department of Agriculture) NRCS (National Recourse Conservation Service) - Soil division website.

The map of vulnerability was prepared using the method of reclassification of the global soil climate map and global soil map. Adding the population density and future trends, the water erosion risk map was prepared. The map was prepared on a scale 1:5,000,000 and the accuracy, i.e. dimension of a grid cell was 2 minutes. Combining the data on erosion vulnerability and the population density, the erosion risk map was prepared.

Figure 3 shows that the WB countries are significantly vulnerable by water erosion processes and the risk of erosion in future is very high.

\section{Water erosion intensity in Europe}

Water erosion intensity in Europe was analyzed using the official reports of the European agencies (EC - European Commission; EEA - European Environment Agency; ES - Eurostat) and the reports from several projects realized in the latest period by JRC - Joint Research Centre of Europe or other scientific institution.

\section{a) EEA - The Dobris Assessment, 1993}

Within EEA (European Environment Agency) annual or periodical reports on the state of the environment there were found data on water erosion in Europe.

The first report in which there was data about water erosion on European level is "European Environment - The Dobris Assessment" 1993. This publication summarizes the major report on the European environment which has been prepared by the EC Task Force for the European Environment Agency in cooperation with the UNECE, UNEP, OECD, Council of Europe, WHO, IUCN and Eurostat, together with the individual countries of Europe. Called Europe's Environment: The Dobris Assessment, this report covers the state of the environment in Europe of nearly 50 states.

This map was prepared using GLASOD approach in a scale 1:30,000,000.

According to this report soil erosion in Europe affects 115 million ha causing loss of fertility and water pollution. According to the above map, the Western Balkan countries perform "the red zone" of water erosion intensity in Europe.

\section{b) SERA (Soil Erosion Risk Assessment) in} Europe (Knijf et al. 2000)

In the recent 10-15 years, there were launched several projects on European level which objective was to develop an erosion map of the EU countries or whole Europe.

Knijf et al. (2000) used USLE method to calculate intensity of rill and inter-rill erosion in EU countries. The map does not cover WB countries. The only parameter that was calculated on European level was the $\mathrm{K}$-factor. According to the map, soil erodibility factor $(\mathrm{K})$ is the highest in Albania and Kosovo. 

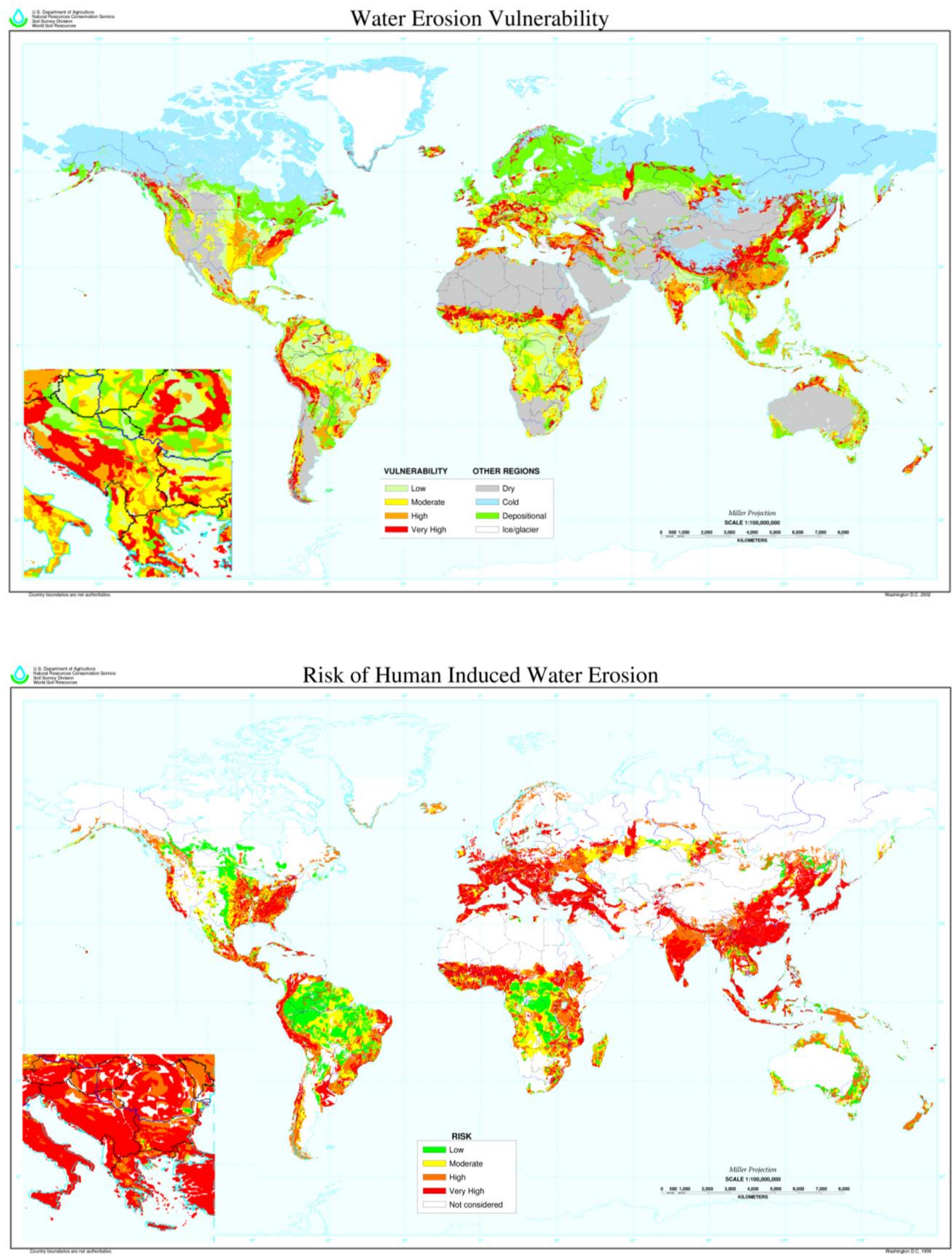

Figure 3 - Water erosion vulnerability in the world and WB (USDA, NRCS) http://www.nrcs.usda.gov/wps/portal/nrcs/detail/soils/use/?cid=nrcs142p2_054006 http://www.nrcs.usda.gov/wps/portal/nrcs/detail/soils/use/?cid=nrcs142p2_054005 


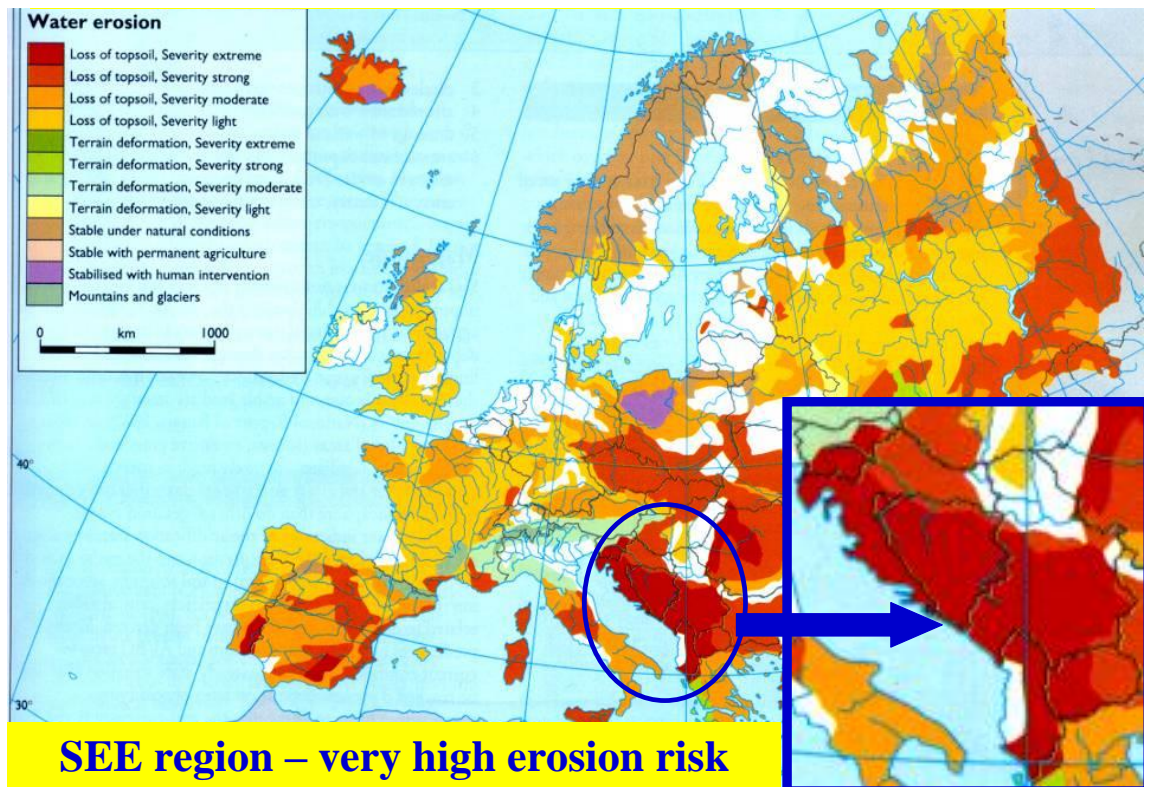

Figure 4. Water erosion in Europe (EEA, The Dobris Assesment, 1993)
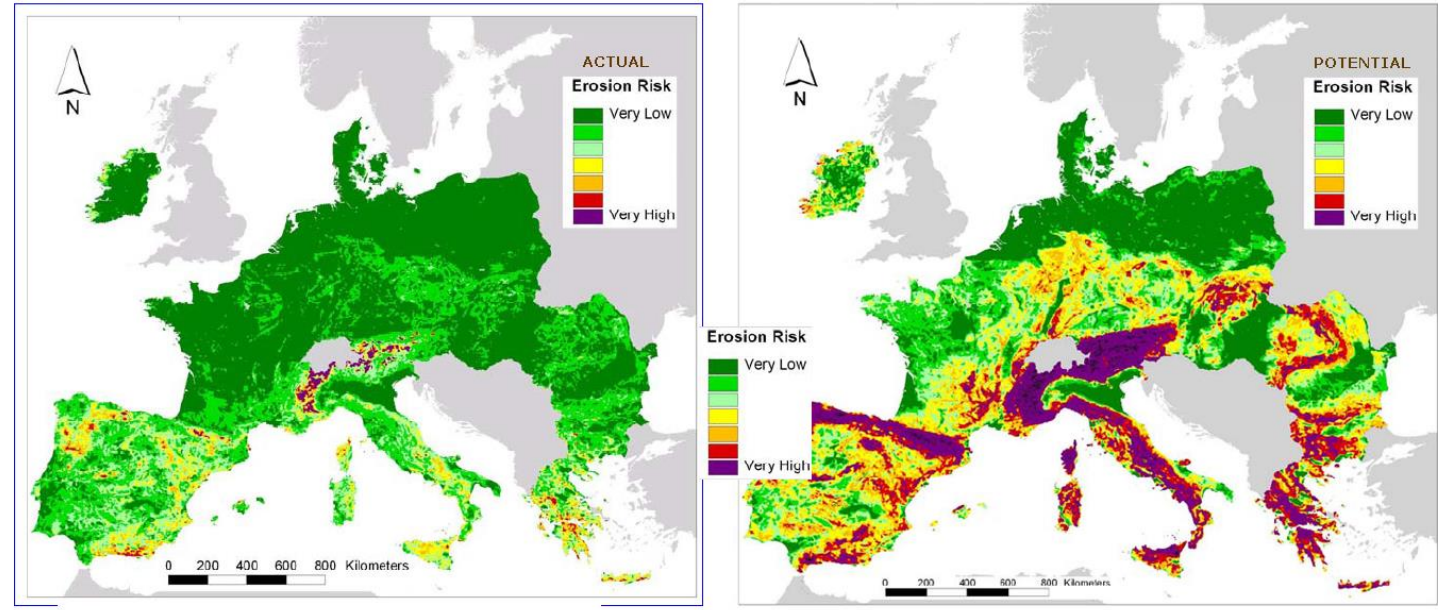

Figure 5. Actual and potential erosion risk (rill and inter-rill erosion) - Knijf et al., 2000

c) MESALES (Modèle d'Evaluation Spatiale de l'ALéa Erosion des Sols - Regional Modeling of Soil Erosion Risk) project

This project was launched by INRA (Institut National de la Recherche Agronomique). It should be considered as an intermediate step towards a "state-ofthe-art erosion modeling at the European scale", subsequent to the work of Van der Knijf et al. (2000) and prior to the initiation of the PESERA project.

The goal of this work was to develop and apply a methodology based on present knowledge and available data for the assessment of soil erosion risk at the European scale. Factors influencing erosion have been graded for the diverse geographical situations existing in Europe and erosion mechanisms have been expressed with the help of experimental and expert-defined empirical rules. Land cover and crust formation on cultivated soils were considered as key factors influencing runoff and erosion risk. A soil geographical database has been created for $\mathrm{Eu}-$ rope, and a model of erosion risk has been developed using a Geographical Information System (GIS). The model uses empirical rules to combine data on land use (CORINE Land Cover database), soil crusting susceptibility, soil erodibility (determined by pedotransfer rules from the Soil Geographical Data Base of Europe at scale 1:1 million), relief (USGS HYDRO1K digital elevation model), and meteorological data at a $1 \times 1 \mathrm{~km}$ pixel size (Space Applications Institute, Ispra Joint Research Center).

The news of this project, beside the way of aggregation of input parameters, was the calculation of erosion intensity per season taking into consideration the variability of rainfalls and land cover 
difference in different seasons of the year. All basic data on erosion risk modeling using MEASLES methodology are given for all Europe countries.

Unfortunately, final results for erosion intensity in the WB countries are missing.

Beside calculation on a pixel level, erosion risk was calculated on a watershed level and NUT 3 region level.

\section{d) PESERA project, 2003}

The PESERA (Pan-European Soil Erosion Risk Assessment) model is a physically based and spatially distributed model developed for quantifying soil erosion in environmentally sensitive areas relevant to a regional or European scale and defining soil conservation strategies.

Unlike USLE method, PESERA philosophy is different. The PESERA model combines the effect of topography, climate and soil into a single integrated forecast of runoff and soil erosion. The model is built in three conceptual stages:

- a storage threshold model to convert daily rainfall to daily total overland flow runoff;

- a power law to estimate sediment transport from runoff discharge and gradient, and interpret sediment transport at the base of the hillside as average erosion loss;

- integration of daily rates over the frequency distribution of daily rainfalls to estimate long-term average erosion rates, (PESERA, Kirkby et al., 2003).

Soil erosion estimates (t/ha/yr) were done by applying the PESERA GRID model at $1 \mathrm{~km}$, using the European Soil Database, CORINE land cover, climate data from the MARS Project and a Digital Elevation Model. The results were the estimates of sediment losses caused by water erosion. The PESERA model produces results that depend crucially on land cover as identified by CORINE and the accuracy of the interpolated meteorological data.

Although almost all input parameters/factors are developed for whole Europe, the final map is prepared only for EU countries.

Beside increased accuracy of presentation, all data is prepared to be available in a ESRI GIS format according to the INSPIRE directive and the user can navigate on the map through European Soil Data Center (ESDAC) MapViewer.

\section{e) EEA report - data and maps, 2012}

Water erosion intensity, i.e. soil loss, is calculated by the Revised Universal Soil Loss Equation (RUSLE). While the overall patterns of erosion are generally sound, the validation of erosion data can be challenging. The data presented are currently being validated through comparisons with national datasets and expert judgment. In this sense, zooming in on a specific locality can give the impression of a situation that differs from reality. In addition, the model used in this exercise does not consider localised intense precipitation. http://www. eea.europa.eu/data-and-maps/figures/estimated-soilerosion-by-water

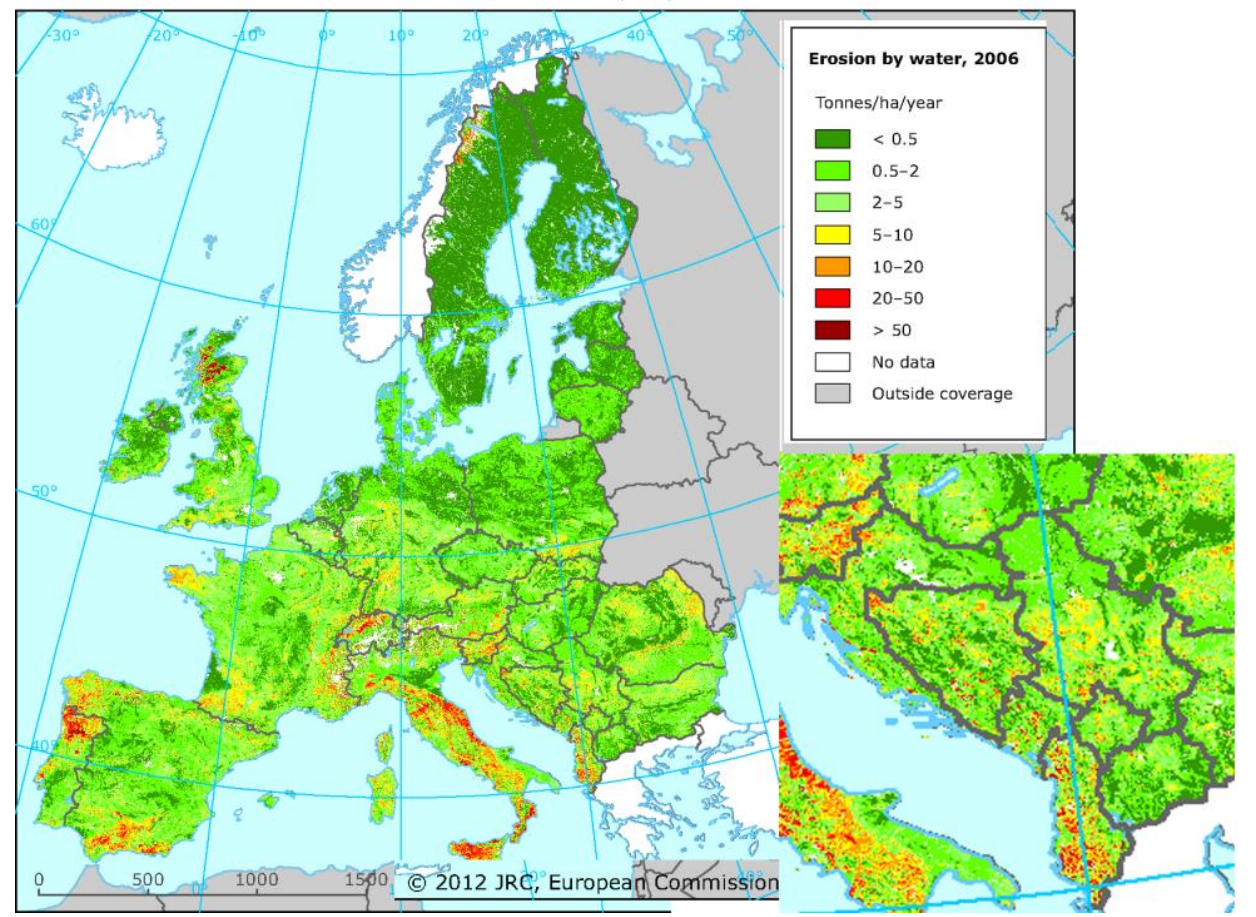

Figure 6. Erosion by water using RUSLE (rill and inter-rill erosion) 
Data source:

- The State of Soil in Europe provided by Joint Research Centre (JRC),

- E-OBS provided by ENSEMBLE FP6 project,

- Corine Land Cover 2006 seamless vector data provided by European Environment Agency (EEA),

- Modeling soil erosion at European scale: towards harmonization and reproducibility. provided by Joint Research Centre (JRC).

The RUSLE model estimates only rill and inter-rill erosion and this is its main disadvantage. The above map shows that risk of rill and inter-rill erosion is the highest in Albania comparing only the WB countries. According to this map, the highest erosion risk in the Republic of Macedonia is calculated in parts of the mountains: Skopska Crna Gora, Suva Gora, Shara, Dautica and Korab. If we compare this map with the national database, there is a discrepancy.

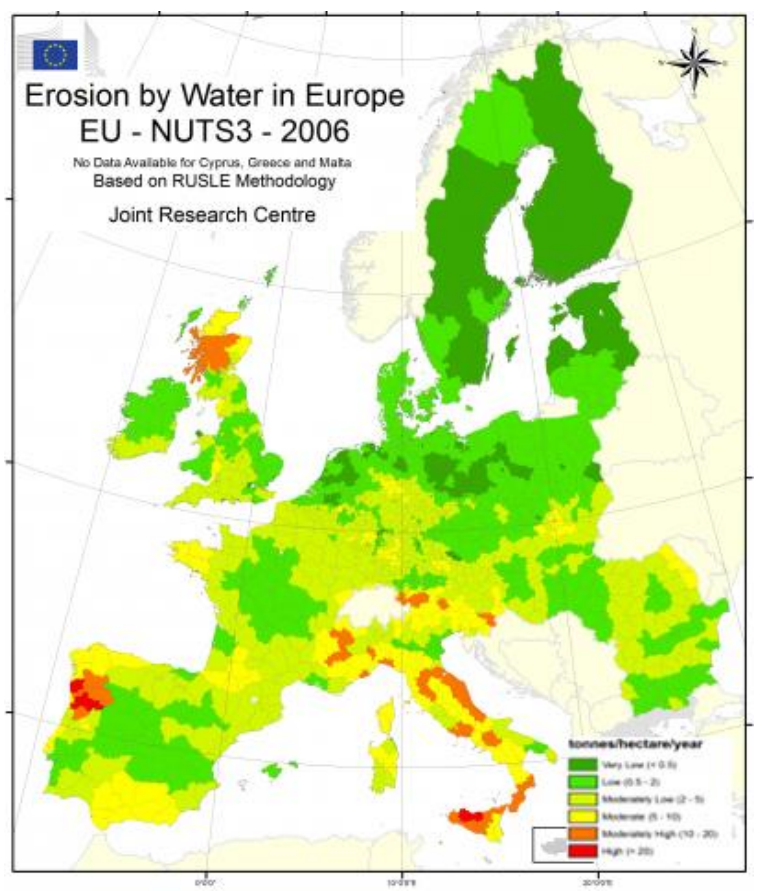

Figure 7. Water erosion map and changes in erosion risk per NUTS3 regions

Within this report there are data about some WB countries (Croatia, Macedonia, Albania and Bosnia and Herzegovina), too.

\section{Western Balkan Countries - national researches}

General official data on erosion intensity in the WB countries was developed in the 1980s and 1990s. Common characteristics for former Yugo-

\section{f) EC - Eurostat: Agri-environmental indi-} cator - soil erosion, 2013

This article provides a fact sheet of the European Union (EU) agri-environmental indicator soil erosion. It consists of an overview of recent data, complemented by all informations on definitions, measurement methods and context needed to interpret them correctly. The soil erosion article is part of a set of similar fact sheets providing a complete picture of the state of the agri-environmental indicators in the EU. The soil erosion indicator estimates the areas affected by a certain rate of soil erosion by water. Main indicator is areas with a certain level of erosion (aggregated to NUTS 3 regions). Supporting indicator is estimated soil loss by water erosion (tones per ha per year).

It is interesting that besides the usual map of estimated erosion risk, there was created a map of changes of erosion risk based on Corine Land cover/use changes data.

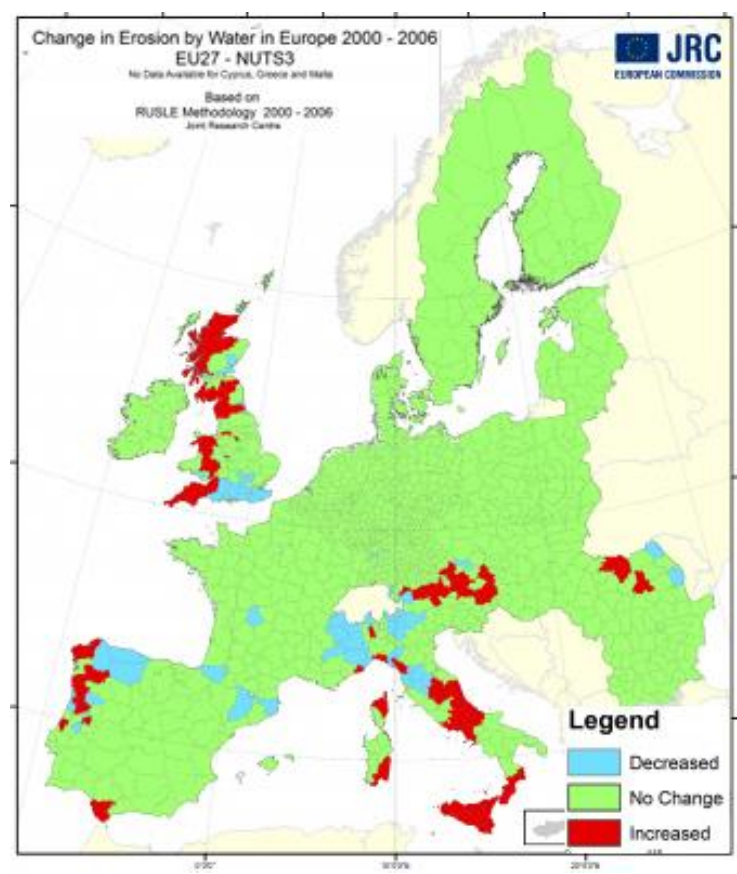

slav countries are that erosion maps were created using EPM - Erosion Potential Method. All maps were created using expert judgment approach through direct on-field mapping of erosion processes on a scale 1:50 000. This data was later digitized (scanned, georeferenced and vectorized) in a GIS environment. In the past 15 years there were a lot of studies in which the erosion intensity was calcu- 
lated using modeling in a GIS environment, but those studies were launched only for some parts of the country, and not for the whole country. Only the current erosion map of Albania was prepared using modeling approach in a GIS environment, although there is a data from erosion mapping in the past.

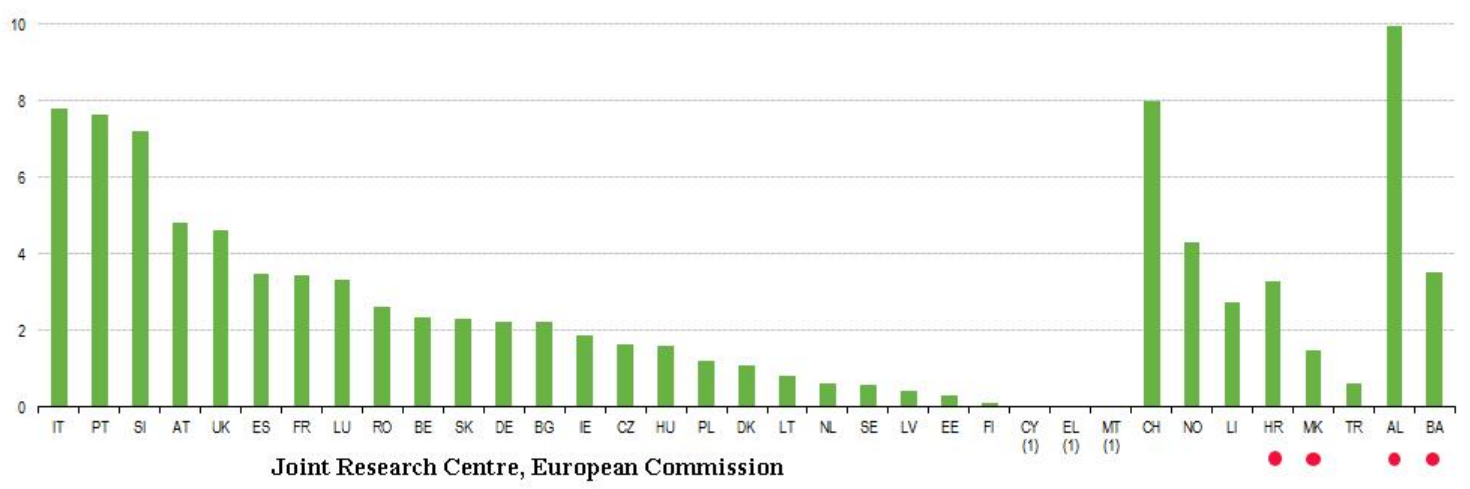

Figure 8. Soil water erosion rate by country (tones per ha per year), 2006, EU-27, EFTA, Candidate and Potential Candidate Countries

\section{a) Albania}

For this purpose there were analyzed several papers edited in various journals or proceedings. According to Zdruly et al. (2001) estimated soil erosion values vary from $32 \mathrm{t} / \mathrm{ha}$ up to $185 \mathrm{t} / \mathrm{ha}$. The estimated area where erosion is the most constraining factor of sustainable development is about 350,000 ha. Grazhdani (2006) stated that the maximum erosion intensity in Albania achieved 510 t/ha y in Gjirokaster. Grazdani presented the mean annual sediment yield in the main rivers. Basin areas of these rivers cover $18,343 \mathrm{~km}^{2}$ or $63.8 \%$ of the whole territory.

Table 2. Mean sediment yield in river basins in Albania (Grazhdani, 2006)

\begin{tabular}{lcc}
\hline River basin & Basin area & Sediment yield \\
\cline { 2 - 3 } & $\mathrm{km}^{2}$ & $\mathrm{t} /$ ha.ann \\
\hline Drini & 5973 & 18.8 \\
Mati & 2441 & 9.3 \\
Fani & 1076 & 11.1 \\
Erzeni & 760 & 26.6 \\
Shkumbini & 2444 & 23.7 \\
Semani & 5649 & 20.9 \\
Vjosa & 6706 & 13.5 \\
\hline Total & 18343 & 18.7 \\
\hline
\end{tabular}

Boriçi et al. (2010) researched stream bank erosion and their results revealed that on some river segments (300-500 m) soil losses are from 23,000 to $26,000 \mathrm{~m}^{3} /$ vit. Study results show that 109,000 ha are endangered soils from the slips and demolitions, while 4000 ha are destructed and slipping soils. Approximations made on a country's river banks show annual losses of several dozen hectares of land.

Binaj et al. (2014) cited several previous researches as follows: Soil erosion affects about 350,000 ha of agricultural land, with a total loss of 60 million tons of solid materials (World Bank, 2007), while the total nutrient loss from erosion is assessed at about 100,000 tons of N, 60,000 tons of $\mathrm{P}$ and 16,000 tons of $\mathrm{K}$.

The most comprehensive research on water erosion was done by Grazhdani et al., edited in $A n$ approach to mapping soil erosion by water with application to Albania, 2006.

Water erosion intensity was presented using new specific modeling in a GIS environment. An one-dimensional hydrology, vegetation and erosion model (RDI/CSEP) is used to calculate accumulative soil erosion. This model provides an integrating of the climatic, topography and associated vegetation components into soil erosion modeling. The forecast runoff, accumulated across the frequency distribution of storms, is used to give a climatic potential, which is then appropriately combined with measures of topography and soil erodibility to estimate the expected rate of soil erosion at a resolution of $1 \mathrm{~km}$. The approach to evaluation and mapping soil erosion by water uses existing soil maps, land use maps, a digital elevation model $(1 \mathrm{~km})$, and interpolated climate data. The characteristic of this research is that erosion modeling was done per month and on an annual level.

Albania is clearly a country where soil erosion by water is a potential problem. The erosion 
conditions (climate, land use and topography) are extreme and conservation measures are urgently needed. Analyses of erosion factors show low values of soil storage and sparse land cover, especially in October and November. Erosion rates are high. For a considerable area the estimated erosion rates are more than $10 \mathrm{t} \mathrm{ha}^{-1} \mathrm{y}^{-1}$, especially in the south and the central part of the country. There are three areas where the annual erosion rate is more than $100 \mathrm{t} \mathrm{ha}^{-1} \mathrm{y}^{-1}$ (two in Gjirokastër and one in Sarandë). Erosion rates are highest in October, November, February and December and lowest in June and July $\left(<1 \mathrm{ha}^{-1} \mathrm{y}^{-1}\right)$. These rates show that erosion in most cases is not well controlled and the most appropriate soil management practices are not being applied (Grazhdani et al., 2006).

\section{b) Bosnia and Herzegovina}

The designing of the Erosion Map of the Republic of Bosnia and Herzegovina $(\mathrm{RBiH})$ began in 1979, its intense design lasted for 7 years, and was completed in 1985. The Erosion Map was created in accordance with the methodology of Dr. Slobodan Gavrilović, and it was amended and modified by a new method of determining the coefficients of erosion by Radenko Lazarević. The map was designed on topographic maps scale 1:25,000 and had a total of 432 sheets (sections), which covered the entire territory of the RBiH. The Erosion Map was prepared in two copies. During the war in 1992-1995 both copies were destroyed. The total average amount of sediment created on the territory of Bosnia and Herzegovina per year was 16,518,031 $\mathrm{m}^{3}$, or $323 \mathrm{~m}^{3} / \mathrm{km}^{2}$. The strongest erosion affected the Krka river basin (Butišnica) and the rivers of Kupa and Ukrina. The weakest erosion was recorded at the immediate catchment area of the Sava river basin and the Adriatic sea. According to the Erosion Map, every year 8,805,286 $\mathrm{m}^{3} /$ year, or 193 $\mathrm{m}^{3} / \mathrm{km}^{2} /$ year of the total sediment production is permanently lost or transported in the Republic of Bosnia and Herzegovina. (Lazić Z., 2012)

So far, only the erosion map of the Republika Srpska has been prepared using two methodologies: USLE - used only for agricultural land by Predić, and using EPM - on a watershed level by Tošić.

Even in the newest documents (National Action Plan to Combat Land Degradation and Desertification in Bosnia and Herzegovina - working version) there is no new erosion map that means it is still in a preparation.

For later comparison there will be used the old existing data from the erosion map of Bosnia and Herzegovina prepared in 1985.

\section{c) Croatia}

Erosion data for Croatia was not sufficiently available. There is old data for the territory of the Sava river basin that belongs to Croatia. This data was produced using EPM methodology. On the other hand, there is a map of erosion using RUSLE produced by JRC. According to the old data on the Sava river basin (Bekić et al.), total mean annual production of erosive material (erosion production by Gavrilović) is $\mathrm{W}=9,085,179 \mathrm{~m}^{3}$ or $\mathrm{W}_{\mathrm{sp}}=352$ $\mathrm{m}^{3} / \mathrm{km}^{2}$ ann. Mean annual transported sediment quantity is $\mathrm{G}=3,361,784 \mathrm{~m}^{3}$ or $\mathrm{G}_{\mathrm{sp}}=130 \mathrm{~m}^{3} / \mathrm{km}^{2}$ ann. The Sava river basin covers in Croatia 25,770 $\mathrm{km}^{2}$, that is $45.5 \%$ of the whole territory.

Using the CORINE approach, Husnjak et al. (2008) estimated soil erosion risk on the territory of the Republic of Croatia at a scale 1:300,000. The authors developed a map of actual and potential erosion risks.

Table 3. Actual and potential erosion risks in Croatia

\begin{tabular}{lcccc}
\hline \multirow{2}{*}{$\begin{array}{l}\text { Class of } \\
\text { erosion risk }\end{array}$} & ha & $\%$ & Pctual & $\%$ \\
\cline { 2 - 5 } Low & 3020690 & 54.3 & 2397410 & 43.1 \\
Moderate & 1796921 & 32.3 & 1366411 & 24.6 \\
High & 746475 & 13.4 & 1800265 & 32.4 \\
\hline Total & 5564086 & 100.0 & 5564086 & 100.0 \\
\hline
\end{tabular}

The authors made additional analyses for agricultural land. On $53.6 \%$ of the agricultural land the determined water erosion risk was low, on $23.1 \%$ it was moderate, and on $23.3 \%$ it was high. The land area characterized by moderate and high risk indicates a great danger of water erosion risk on the larger part of the cultivated agricultural land in Croatia (46.4\%).

\section{d) Serbia, Montenegro and Kosovo}

Data on erosion intensity in all three countries were provided by Kostadinov et al. (2006).

The erosion map of Serbia (including Kosovo) was made in 1973 using EPM methodology. This map shows that, of the total area of Serbia, $86.00 \%$ is endangered by erosion processes of vari- 
ous intensity: Vojvodina $72.29 \%$, Kosovo and Metohia $94.82 \%$. A new map of erosion was produced in 1984. Total average annual gross erosion in Serbia is $37,249,975.0 \mathrm{~m}^{3} \cdot \mathrm{y}^{-1}$, specific annual gross erosion amounts to $421.57 \mathrm{~m}^{3} \cdot \mathrm{km}^{-2} \cdot \mathrm{y}^{-1}$, annual sediment transport is $9,350,765.0 \mathrm{~m}^{3} \cdot \mathrm{y}^{-1}$, specific annual sediment transport is $105.80 \mathrm{~m}^{3} \cdot \mathrm{km}^{-2} \cdot \mathrm{y}^{-1}$.
Permanent soil loss in Serbia is 487.86 $\mathrm{m}^{3} \cdot \mathrm{km}^{-2} \cdot \mathrm{y}^{-1}$, Kosovo and Metohia $248.98 \mathrm{~m}^{3} \cdot \mathrm{km}^{-2} \cdot \mathrm{y}^{-1}$.

The most endangered region in Serbia is the southeast part of the country that is close to the borders with Macedonia and Bulgaria (Kostadinov et al., 2006).

Table 4. Erosion distribution in Serbia, Kosovo and Montenegro (Kostadinov et al., 2006)

\begin{tabular}{|c|c|c|c|c|c|c|}
\hline \multirow{2}{*}{\multicolumn{2}{|c|}{$\begin{array}{l}\text { Degradation category - } \\
\text { Erosion process intensity }\end{array}$}} & \multirow{2}{*}{$\begin{array}{l}\text { Erosion intensity } \\
\quad\left(\mathrm{m}^{3} \mathrm{~km}^{2} \cdot \mathrm{y}^{-1}\right)\end{array}$} & \multicolumn{2}{|c|}{ Serbia (incl. Kosovo) } & \multicolumn{2}{|c|}{ Montenegro } \\
\hline & & & \multirow{2}{*}{$\frac{\mathrm{km}^{2}}{2888}$} & \multirow{2}{*}{$\begin{array}{c}\% \\
3.27\end{array}$} & \multirow{2}{*}{$\frac{\mathrm{km}^{2}}{180}$} & \multirow{2}{*}{$\begin{array}{c}\% \\
1.3\end{array}$} \\
\hline I & Excessive & $>3000$ & & & & \\
\hline II & High & $1500-3000$ & 9138 & 10.34 & 1354 & 9.8 \\
\hline III & Moderate & $1000-1500$ & 19386 & 21.94 & 5027 & 36.4 \\
\hline IV & Weak & $500-1000$ & 43914 & 49.78 & 6367 & 46.1 \\
\hline \multirow[t]{2}{*}{ V } & Very weak & $70-500$ & 13035 & 14.75 & 884 & 6.4 \\
\hline & Total & & 88361 & 100 & 13812 & 100 \\
\hline
\end{tabular}

Note: Separate data about Kosovo was not available

\section{e) Republic of Macedonia}

The Erosion Map of the Republic of Macedonia was prepared by the scientists from the Water Development Institute of the Republic of Macedonia (Gorgević M., Jelić D., Trendafilov A., Georgievski S., Popovski A.,) using the EPM Gavrilović methodology through direct on-field mapping of erosion intensity in the period of the 1980s. Synthetic report was launched in 1993. Later, the working maps were scanned, georeferenced and vectorized. Additional research in the later period was done by Trendafilov and Blinkov in some parts of the country, and small part of original data was updated. According to the Erosion map of Macedonia, cca $96 \%$ of the total area is affected by erosion. An area of $9,423 \mathrm{~km}^{2}$ or $36.65 \%$ of the total state area is in the highest categories (I-III). The total annual erosion in Macedonia is about $17 \cdot 10^{6}$ $\mathrm{m}^{3} \cdot \mathrm{y}^{-1}$ or $685 \mathrm{~m}^{3} \cdot \mathrm{km}^{-2} \cdot \mathrm{y}^{-1}$, with about $7.5 \cdot 10^{6} \mathrm{~m}^{3} \cdot \mathrm{y}^{-1}$ or $303 \mathrm{~m}^{3} \mathrm{~km}^{-2} \cdot \mathrm{y}^{-1}$ of the sediment moved away from the site where it is eroded. A significant part of these deposits within Macedonia, about $3 \cdot 10^{6} \mathrm{~m}^{3} \cdot \mathrm{y}^{-1}$, is not carried through the downstream sections of the rivers to the exit of the state territory, but is deposited in natural lakes and reservoirs. According to the calculation of Gorgevic et al., based on the erosion map, the rates of annual sediment yield to the biggest reservoirs in Macedonia are: Tikveš $\left(1.3 \cdot 10^{6} \mathrm{~m}^{3}\right.$ or $\left.497 \mathrm{~m}^{3} \cdot \mathrm{km}^{-2}\right)$, Kalimanci $\left(0.42 \cdot 10^{6} \mathrm{~m}^{3}\right.$ or $970 \mathrm{~m}^{3} \cdot \mathrm{km}^{-2}$ ).

Table 5. Erosion distribution in Macedonia (by EPM methodology)

\begin{tabular}{lcccc}
\hline $\begin{array}{l}\text { Degradation category } \\
\text { (Erosion process) }\end{array}$ & $\begin{array}{c}\text { Area } \\
\left(\mathrm{km}^{2}\right)\end{array}$ & $\begin{array}{c}\text { Percent } \\
(\%)\end{array}$ & $\begin{array}{c}\text { Erosion intensity } \\
\left(\mathrm{m}^{3} \mathrm{~km}^{2} \cdot \mathrm{y}^{-1}\right)\end{array}$ \\
\hline I & Excessive & 698 & 2.77 & $>3000$ \\
II & High & 1832 & 7.38 & $1500-3000$ \\
III & Moderate & 6893 & 27.78 & $1000-1500$ \\
IV & Weak & 7936 & 31.98 & $500-1000$ \\
V & Very weak & 7463 & 30.09 & $70-500$ \\
\hline
\end{tabular}

In the recent period there were realized several projects, modeling of erosion intensity in a GIS environment using EPM in different regions in Macedonia by Blinkov I., Milevski I., Minčev I.,
Kojčevska T., Trendafilov B., or USLE by Mukaetov D., but official modeling of erosion intensity on the whole territory of the Republic of Macedonia has not been done yet. 


\section{Comparison of erosion intensity between $\mathrm{EU}$ and Balkan countries}

Data on erosion intensity expressed in t/ha for the EU countries was extracted from the EU-27 EFTA report (2006).

For Bosnia and Herzegovina, Serbia, Montenegro, Kosovo and Macedonia, data from erosion mapping in the 1980s was used.

Data for Croatia (obtained by Husnjak et al.) was converted to be comparable with the others using the mean values of any category.

For Albania, data on sediment yield obtained by Grazhdani S. (2006) was used, but although the- se results cover only $64 \%$ of the territory they were converted for the whole territory.

The region of Western Balkan countries having an area of $263,472 \mathrm{~km}^{2}$ is a highly erosive part of Europe. The total annual erosion production for the region of Western Balkan is about $374 \cdot 10^{6} \mathrm{~m}^{3} \cdot \mathrm{y}^{-1}$ or $656 \mathrm{~m}^{3} \mathrm{~km}^{-2} \cdot \mathrm{y}^{-1}$.

Values from the national reports are higher because within the EFTA report data on erosion mapping was presented using RUSLE method that recognizes only rill and inter-rill erosion, while EPM (used for erosion mapping in RM, CRO and $\mathrm{BiH}$, as well as one-dimensional model in Albania) recognizes all erosion types even streambank and mass movement erosion.

Table 6. A review of erosion intensity in Western Balkan countries

\begin{tabular}{|c|c|c|c|c|c|}
\hline \multirow[t]{3}{*}{ Country } & \multicolumn{2}{|c|}{ Annual erosion intensity } & \multirow{3}{*}{$\begin{array}{c}\text { Erosion } \\
\text { map } \\
\text { scale }\end{array}$} & \multirow{3}{*}{ Methodology } & \multirow{3}{*}{ Source } \\
\hline & Absolute & Specific & & & \\
\hline & $\mathrm{m}^{3}$ & $\mathrm{~m}^{3} / \mathrm{km}^{2}$ & & & \\
\hline Macedonia & $17.0 \cdot 10^{6}$ & 685 & $1: 50000$ & EPM by Gavrilović & Gorgević et al. (1993) \\
\hline Serbia & $37.0 \cdot 10^{6}$ & 488 & $1: 50000$ & EPM by Gavrilović & Kostadinov S. (2007) \\
\hline Kosovo & $2.7 \cdot 10^{6}$ & 289 & $1: 50000$ & EPM by Gavrilović & Kostadinov S. (2007) \\
\hline Montenegro & $17.3 \cdot 10^{6}$ & 1253 & $1: 50000$ & EPM by Gavrilović & Kostadinov S. (2007) \\
\hline $\mathrm{B}$ a H & $16.5 \cdot 10^{6}$ & 323 & $1: 25000$ & EPM by Gavrilović & Lazić Z. (2012) \\
\hline Croatia* & $26.0 \cdot 10^{6}$ & 481 & $1: 300000$ & CORINE model & Hushnjak S. ${ }^{*}(2008)$ \\
\hline Albania* & $53 \cdot 10^{6}$ & 1870 & Pixel $1 \mathrm{~km}$ & RDI/CSEP model & Grazhdani S. * (2007) \\
\hline TOTAL & $373.8 \cdot 10^{6}$ & 656 & & & \\
\hline
\end{tabular}

*Original data expressed in $\mathrm{t} / \mathrm{ha}$ was converted with aim to be comparable

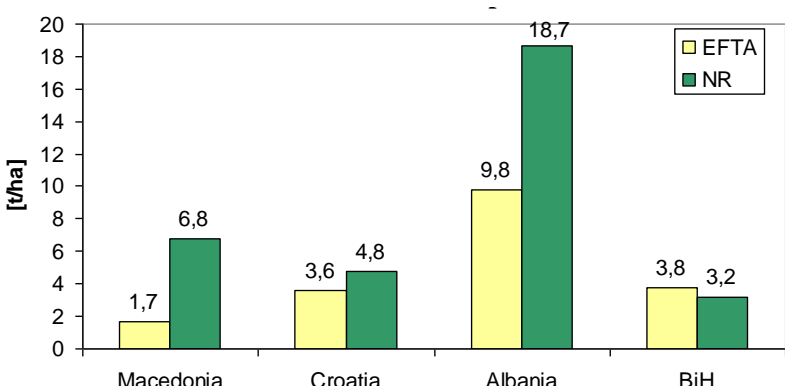

Figure 9. Comparison of erosion intensity per country, EFTA vs. NR

According to the erosion intensity, countries in Europe could be classified in 6 groups. The most endangered countries (>10 t/ha) are Albania and Montenegro. The second group (5-10 t/ha) includes Italy, Portugal, Slovenia, Macedonia and Romania.

It should be stressed that erosion intensity for the EU countries was estimated using RUSLE method that shows lower results within the countries where dominate hilly-mountain an mountain character.

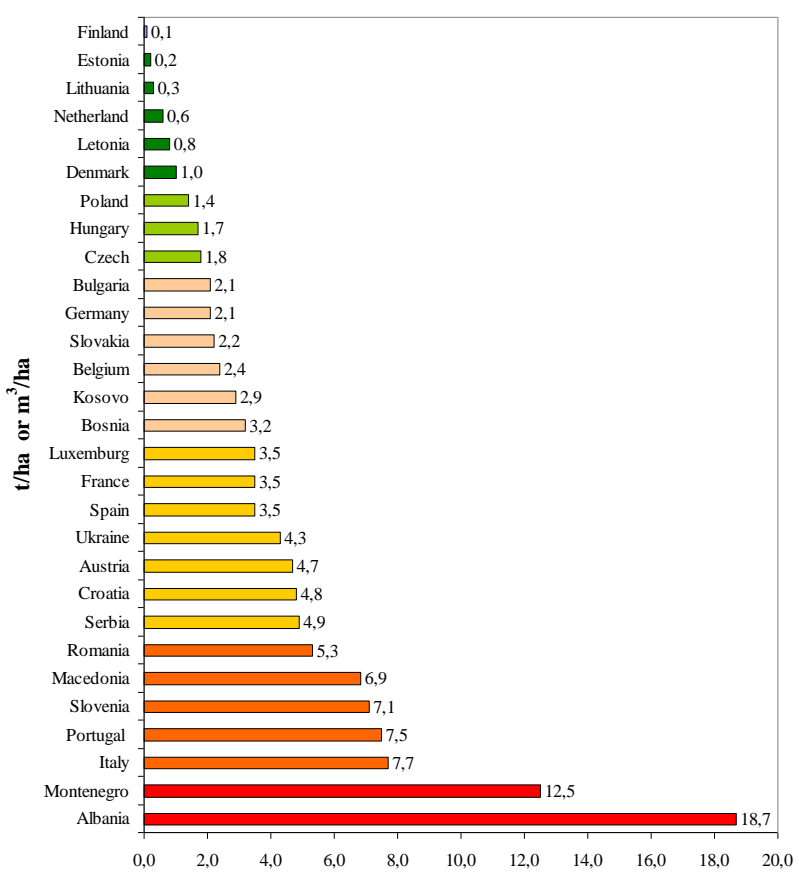

Figure 1. Erosion intensity per country [t/ha] 


\section{CONCLUSIONS}

Analyses show that there are many differences in various reports on erosion. Primarily, there is a terminological difference: erosion risk areas, erosion intensity, endangered areas, etc. Then, the methodologies differ not only on European level but between the WB countries. For the EU countries several erosion maps have been prepared using different methodologies and approaches (RUSLE, CORINE, PESERA, MESALES). All these maps were prepared using modeling in a GIS environment. All existing erosion maps of former Yugoslav countries were prepared in the 1980s using expert judgment on-field mapping method by EPM methodology. In Albania the new erosion map was prepared using specific methodology. In Bosnia and Herzegovina only a new erosion map of the Republika Srpska has been prepared so far, through modeling in a GIS environment using USLE (for agricultural land) and EPM (for the whole territory). In other countries there are only sporadic researches through modeling in a GIS environment that cover only parts of the countries.

On European level data on WB countries is usually missing. In the EU reports there are data on WB countries that are lower then the real. Through the analyses of national researches it was found that erosion intensity in the WB countries is $656 \mathrm{~m}^{3} / \mathrm{ha}$ (similar to $6.56 \mathrm{t} / \mathrm{ha}$ ), and the total amount of annual produced erosive material is $373,8 \cdot 10^{6} \mathrm{~m}^{3}$.

The most erosive countries in Europe are Albania and Montenegro where mean annual intensity of erosion is $>10 \mathrm{t} / \mathrm{ha}$. Macedonia, together with Italy, Portugal, Slovenia and Romania, is in the second group of countries in which erosion intensity is $5-10 \mathrm{t} / \mathrm{ha}$.

Taking into consideration the above facts, it can be recommended that the priority research should be focused on erosion modeling using contemporary methodologies and approaches.

\section{REFERENCES}

[1] Gobin A, G. Govers, R. Jones, M. Kirkby, C. Kosmas, 2002: Assessment and reporting on soil erosion. Background and workshop report, chRepSoilerosFIN110902.pdf http://eusoils.jrc.ec. europa.eu/esdb_archive/pesera/pesera_cd/pdf/

[2] R. P. C. Morgan, 1992: Soil Erosion in the Northern Countries of the European Community. EIW Workshop: Elaboration of a Framework of a Code of Good Agricultural Practices, Brussels, May 2122. (Cited by Monatanrela L.,The EU Thematic Strategy on Soil Protection).

[3] W. Eckelmann, R. Baritz, S. Bialousz, P. Bielek, F. Carre, B. Houskova, R. J. A. Jones, M. G. Kib- blewhite, J. Kozak, C. Le Bas, G. Toth, T. Toth, G. Varallyay, M. Yli Halla and M. Zupan (2006). Common Criteria for Risk Area Identification according to Soil Threats. European Soil Bureau Research Report No.20, EUR 22185 EN, 94pp. Office for Official Publications of the European Communities, Luxembourg.

[4] Philipp Mayring, June 2000: Qualitative Content Analysis Forum Qualitative social research, Volume 1, No. 2, Art. 20, , http://www.qualitativeresearch.net/index.php/fqs/article/view/1089/2385

[5] Eric Roose: Evaluating, Monitoring and Forecasting Erosion, 12th ISCO Conference Beijing 2002, proceedings.

[6] I. Blinkov, S. Kostadinov, 2010: Applicability of various erosion risk assessment methods for engineering purposes, BALWOIS conference, May 25-29, Ohrid, Macedonia.

M. Grimm, R. J. A. Jones, L. Montanarella, 2002: Soil erosion risk assesment in Europe, EC, ESB, JRC, 2002 (revised).

[7] S. Gavrilović, 1972: Inženjering o bujičnim tokovima i erozija, časopis Izgradnja, specijalno izdanje, Beograd.

[8] Global Assessment of Human-induced Soil Degradation (GLASOD) 1990, http://www.isric. org/projects/global-assessment-human-inducedsoil-degradation-glasod

(http://www.worldwildlife.org/threats/soil-erosionand-degradation)

[9] http://english.peopledaily.com.cn/200205/28/eng 20020528 96615.shtml

[10] http://www.nrcs.usda.gov/wps/portal/nrcs/detail/soils /use/?cid=nrcs142p2_054006

[10] http://www.nrcs.usda.gov/wps/portal/nrcs/detail/soils /use/?cid=nrcs142p2_054005

[12] The Dobris Assessment, Europe's Environment.An overview. Editors: David Stanners and Philippe Bourdeau, Produced in 1994 by: Earthscan Publications.

[13] MESALES (Modèle d'Evaluation Spatiale de l'ALéa Erosion des Sols - Regional Modeling of Soil Erosion Risk) project http://eusoils.jrc.ec. europa.eu/ESDB Archive/serae/grimm/erosion/inra/eur ope/analysis/maps_and_listings/web_erosion/index. $\underline{\mathrm{html}}$

[14] M. J.Kirkby, R. J. A. Jones, B. Irvine, A. Gobin, G. Govers, O. Cerdan, A. J. J. Van Rompaey, Y. Le Bissonnais, J. Daroussin, D. King, L. Montanarella, M. Grimm, V. Vieillefont, J. Puigdefabregas, M. Boer, C. Kosmas, N. Yassoglou, M. Tsara, S. Mantel, G.J. Van Lynden, and J. Huting, (2004). Pan-European Soil Erosion Risk Assessment: The PESERA Map, Version 1 October 2003. Explanation of Special Publication Ispra 2004 No.73 (S.P.I.04.73). European Soil Bureau Research Report No.16, EUR 21176, 18pp. and 1 map in ISO B1 format. Office for Official Publications of the European Communities, Luxembourg. 
http://www.eea.europa.eu/data-and-maps/figures/ estimated-soil-erosion-by-water

[15] EC - Eurostat, 2012: Agri-environmental indicator - Soil erosion, http://epp.eurostat.ec.europa.eu/ statistics explained/index.php/Agri-environmental_indicator_-_soil_erosion

[16] P. Zdruli, S. Lushaj : The Status of Soil Survey in Albania and some of its Major Environmental Findings by Pandi Zdruli and Sherif Lushaj, Options Méditerranéennes : Série B. Etudes et Recherches; n. 34), Bari : CIHEAM, 2001. p. 69-97

[17] S. Grazhdani: ch. I.21- Albania, Soil Erosion in Europe, John Boardman and Jean Poesen (Editors), Wiley\&Sons , 2006

[18] Justina Boriçi, Vangjo Kovaçi, Klarent Dedaj, Zaim Mema (2010): Soil Erosion from the River Sides Estimations of Damages and the Improving Measures, BALWOIS 2010

[19] Agim Binaj, Pirro Veizii, Enkeleida Bequraj, Fran GJoka, Elian Kasa, Economic losses from soil degradation in agricultural areas in Albania, Agric. Econ. - Czech, 60, 2014 (6): 287-293

[20] S. Grazhdani, S. Shumka, S. Borgwang, E. Skarboevik, An approach to mapping soil erosion by water with application to Albania, BALWOIS 2006 conference

[21] Z. Lazić, (2012): Bosnia and Herzegovina/Republika Srpska, Practical training course on sustainable sediment management with the Sava river basin as a showcase - International Sava River Basin Commission, Zagreb 15-18 October 2012

[22] D. Bekic, D. Oskorus, (2012): Sediment status Croatia, Practical training course on sustainable sediment management with the Sava river basin as a showcase - International Sava River Basin Commission, Zagreb 15-18 October 2012

[23] Husnjak S., Šimunić I., Tursić I., Soil erosion risk in Croatia, VII. Alps-Adria Scientific Workshop Stará Lesná, Slovakia, 2008.

[24] S. Kostadinov, M. Zlatic, N. Dragovic, Z. Gavrilović: ch. I.22: Serbia and Montenegro, Soil Erosion in Europe, John Boardman and Jean Poesen (Editors), Wiley\&Sons , 2006.

[25] I. Blinkov, A. Trendafilov, ch. I.24: Macedonia, Soil Erosion in Europe, John Boardman and Jean Poesen (Editors), Wiley\&Sons , 2006.

[26] M. Gorgevic, D. Jelic, A. Trendafilov, S. Georgievski, A. Popovski, 1993: Erosion Map of Macedonia, WDI, 1993, Skopje

\title{
ПРЕГЛЕД И КОМПАРАЦИЈА НА ИНТЕНЗИТЕТОТ НА ВОДНАТА ЕРОЗИЈА ВО ДРЖАВИТЕ НА ЗАПАДЕН БАЛКАН И НА ЕУ
}

\author{
Иван Блинков \\ Катедра за земјиште и вода, Шумарски факултет, Универзитет „Св. Кирил и Методиј“ \\ Скопје, Република Македонија
}

Регионот на Јужна и Југоисточна Европа е значително подложен на ерозивни процеси. Во некои делови на регионот, ерозијата ја достигна фазата на неповратност, а во некои места ерозијата е практично завршена, бидејќи не е останата почва. Во изминатиот период беа развиени разни модели и пристапи во ГИС опкружување, при што се користени бази на податоци кои се лесно достапни на европско ниво. Од друга страна, податоци за интензитетот на водната ерозија во државите од Западен Балкан честопати недостигаат на европските карти. Научниците од државите од Западен Балкан се соочуваат со проблемот на ерозијата со години. Развиени се локални/регионални модели и се изработени различни карти на ерозијата со користење национални бази на податоци. Целта на оваа студија е да се споредат резултатите за интензитетот на водната ерозија помеѓу државите од Западен Балкан добиени со национални истражувања со оние резултати добиени со користење модели на пошироко европско ниво. Основниот методолошки пристап во овој труд е анализа на секундарни податоци, со користење на методот на анализи на содржина на различни извори на податоци. Беа користени индуктивни и дедуктивни квалитативни анализи и, на крај, е применет методот на компаративна анализа. Преку анализа на националните истражувања беше добиено дека интензитетот на ерозијата во државите од Западен Балкан изнесува $656 \mathrm{~m}^{3} / \mathrm{ha}$ (приближно 6,56 t/ha), а вкупниот годишен износ на произведен ерозивен материјал е $373,8 * 10^{6} \mathrm{~m}^{3}$. Најерозивни држави во Европа се Албанија и Црна Гора, каде што годишниот интензитет на ерозија е поголем од 10 t/ha. Македонија заедно со Италија, Португалија, Словенија и Романија е во втората група држави, каде што интензитетот на ерозијата се движи 5-10 t/ha.

Клучни зборови: карта на ерозија; интензитет на ерозија; ризик од ерозија 


\section{ANNEX - Erosion maps of WB countries}

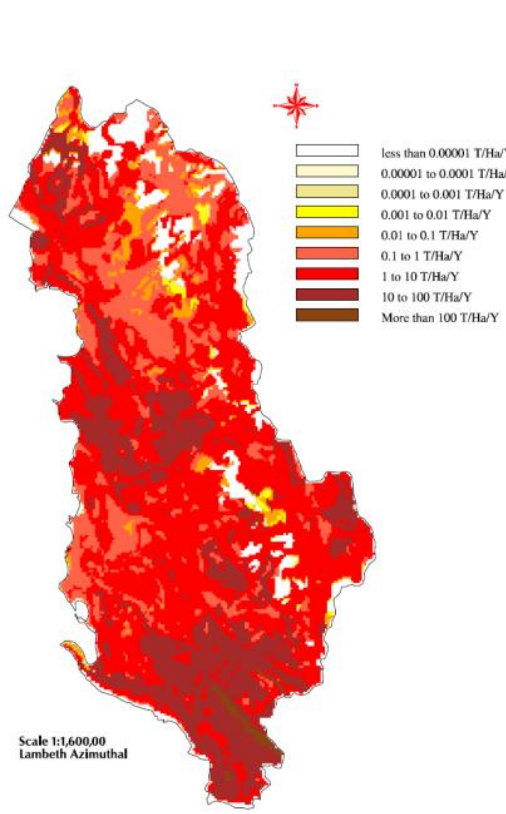

Albania

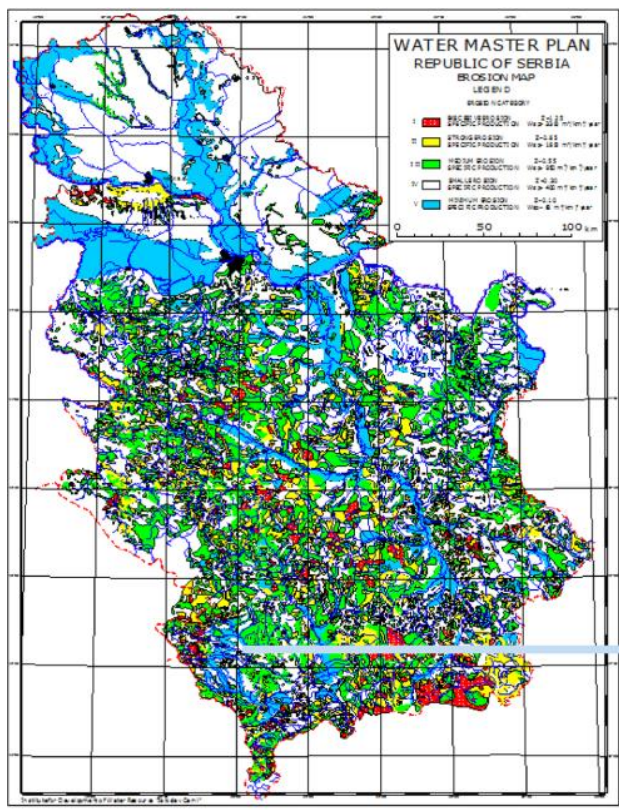

Serbia
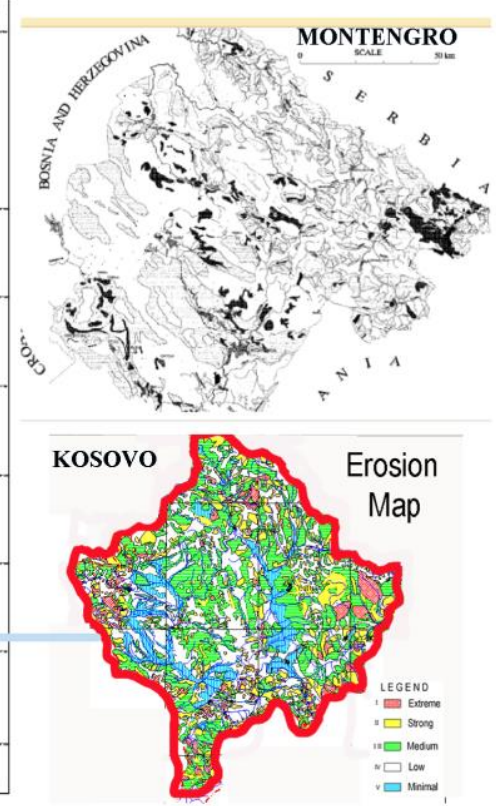

Montenegro / Kosovo

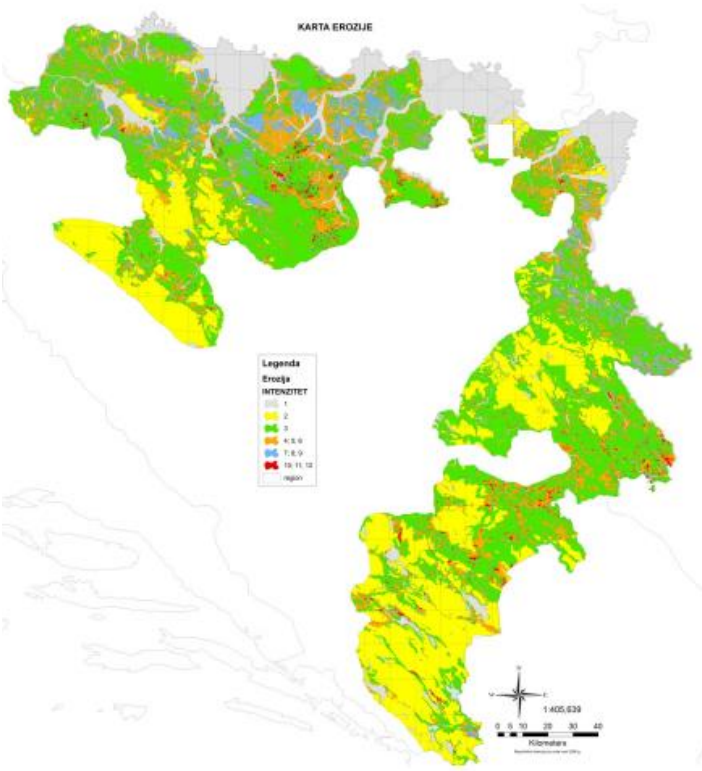

Republika Srpska (Bosnia and Hercegovina)

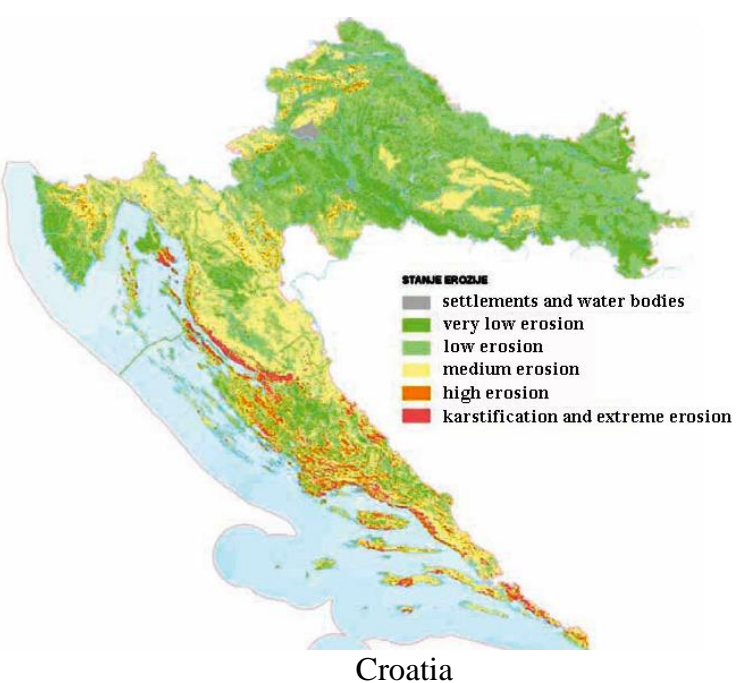

Croatia

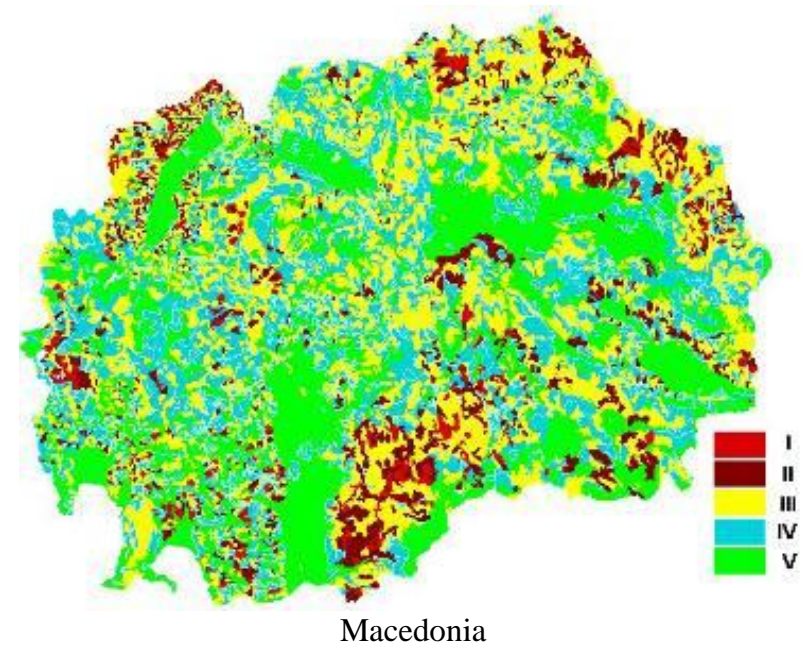

